
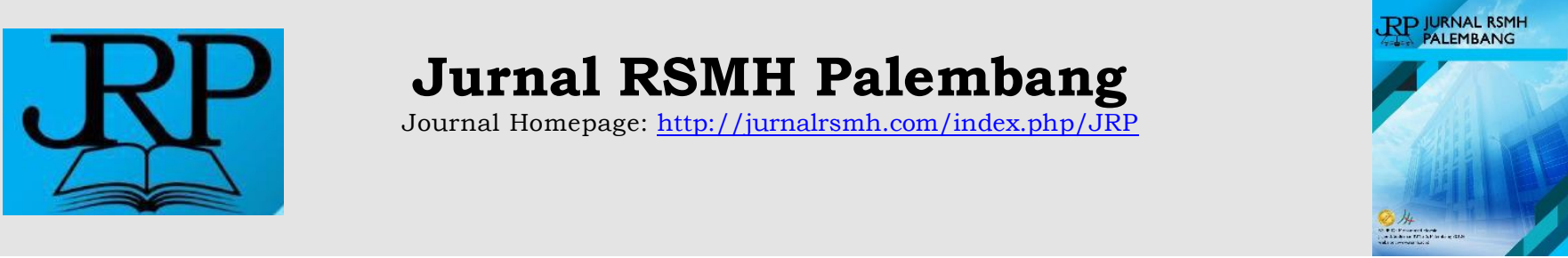

\title{
Superficial mycosis profile in the Tertiary Hospital Dr. Moh. Hoesin Palembang: retrospective research
}

\author{
Desi Harnis ${ }^{1}$, Rusmawardiana ${ }^{2}$, Fifa Argentina ${ }^{3}$ \\ 1,2,3 Department of Dermatology and Venereology, Faculty of Medicine, Sriwijaya University, Palembang
}

\section{A R T I C L E I N F O \\ Keywords: \\ Superficial mycoses \\ Profile retrospective study \\ Corresponding author: \\ Desi Harnis \\ E-mail address: \\ desiharnis.212@gmail.com}

All authors have reviewed and approved the final version of the manuscript.

https://doi.org/10.37275/JRP.v1i1.5

\begin{abstract}
A B S T R A C T
Background Superficial mycoses is a fungal infection of the skin, nails and hair that caused by dematophytes, yeast and mold. Superficial mycoses infections are commonly found in high temperature and humidity area such as Indonesia. Palembang is one of regions in Indonesia has a high temperature and humidity, considered the incidence of this disease is high. A retrospective study of new cases of superficial mycoses, data taken from medical records and register book at Policlinic of Dermatology and Venereology Dr. Moh. Hoesin Palembang during 5 years from January 2014-December 2018. There were $1,236(17.1 \%)$ new cases of superficial mycoses. Incidence of superficial mycoses varies with range 6.9\%-23\%. The most common superficial mycoses is dermatophytes (38,3\%). Microsporum canis, Trichophyton rubrum dan Tricophyton hmentagrophytes are frequent isolates in this study. The most age group is $36-45$ years $(17.6 \%)$ with male more than female. Superficial mycoses are often found in students $(26.9 \%)$, followed by unskilled workers $(20.8 \%)$. Of the 1,236 new cases, 125 patients had comorbidities, such as malignancy $21(16.8 \%)$ patients, cerebrovascular disease and diabetes mellitus each 16 patients $(7.4 \%)$. Inguinal and abdomen are the most commonly infected regions. $656(53.1 \%)$ patients was given topical antifungal. The most common topical antifungal was ketoconazole $2 \%$ cream $(62 \%)$ and systemic antifungal was itraconazole (55,3\%).Conclusion: Cases of superficial mycoses, especially dermatophytosis and Malassezia were still commonly found, especially in Palembang.
\end{abstract}

\section{Introduction}

Fungal infections, often called mycoses, can be divided into superficial mycosis, subcutaneous mycosis and systemic mycosis. ${ }^{1}$ Superficial mycosis is a superficial fungal infection of the skin, nails, and hair caused by dermatophytes, yeast and molds. ${ }^{2}$ Diseases that include superficial mycosis include dermatophytosis, pityriasis versicolor, Malassezia folliculitis and superficial candidiasis. ${ }^{3}$

Although superficial dermatomycosis rarely causes death, it generally interferes with the quality of life and daily activities. ${ }^{2}$ Until now, superficial dermatomycosis is still common worldwide and is still a general health problem, especially in developing countries..$^{2,4}$ It is estimated that superficial mycosis affects more than $25 \%$ of the world's population. ${ }^{1}$ Superficial mycosis is quite common in tropical countries. The tropical climate in Indonesia with high temperature and humidity is a good environment for fungal growth and it is estimated that the incidence of this disease is quite high and can be found in all places. Data from various general public medical teaching hospitals in Indonesia in 2009-2011 showed that the lowest proportion of superficial mycosis to dermatoses was in Yogyakarta at $4.06 \%$ and the highest was in Semarang at 26.4\% 5 
Superficial mycosis is influenced by several factors such as socioeconomic, age, malnutrition, personal hygiene, congested living conditions, immunosuppressive conditions such as diabetes mellitus, human immunodeficiency virus (HIV), cancer or malignancy.6,7 Some activities and habits are also associated with fungal infections. such as contact with animals, sports, wearing closed shoes, wearing tight clothing. 8 Diagnosis of superficial mycosis is based on history, clinical examination, and direct mycological examination using potassium hydroxide $(\mathrm{KOH})$ and culture or culture. 9

Superficial mycosis infection is still a major health problem in most countries, so epidemiological data are important to improve strategic planning and disease eradication. ${ }^{6}$ This retrospective study aims to determine an overview of superficial dermatomycosis in the Dermatology and Venereology Polyclinic of Dr. Moh. Hoesin Palembang for the period 2014-2018.

\section{Research Methods}

This retrospective descriptive study used data taken from the register book and medical records of patients with superficial dermatomycosis who were registered at the Dermatology and Venereology polyclinic, Dr. Moh. Hoesin Palembang for 5 years from 2014 to 2018. The population includes all new cases recorded as having skin diseases at the Dermatology and Venereology Polyclinic, Dr. Moh. Hoesin Palembang. The sample of the study were all new cases diagnosed with superficial dermatomycosis in the Dermatology and Venereology Polyclinic, Dr. Moh. Hoesin Palembang. All data were processed using the Statistical Analysis Software Package (SPSS) version 22.0 (IBM Corporation).

\section{Results}

During the January 2014-December 2018 period, the number of new patient visits at the DV Polyclinic RSMH Palembang was 7,250 patients. Of these, 1,238 $(17.1 \%)$ new patients with superficial mycosis were found. The incidence of superficial mycosis shows different results each year, ranging from $6.9 \%$ to $23 \%$. The highest incidence was found in 2016. (Table 1).
Based on the type of superficial mycosis, dermatophytosis was the most common case of 473 (38.3\%) and then Malassezia of 437 (35.4\%), but in terms of each diagnosis, pityriasis versicolor was the most common case, 428 (34 6\%) patients, followed by tinea corporis in 437 (38.3\%). From the culture, it was found that Microsporum canis, Trichophyton rubrum and Trichophyton mentagrophytes were mostly found. This study also found 181 (14.6\%) patients had a mixed diagnosis, most of which were 162 patients with tinea corporis et kruris (Table 2 and Figure 1).

Based on the age group, the most cases of superficial mycosis were between the ages of 26-35 years with 217 patients (17.5\%) followed by the 17-25 years age group for 207 patients (16.7\%) as in Table 3.The mean age of superficial mycosis patients was $32.08 \pm 17.94$ (mean SD), the youngest subject was 1 month old and the oldest was 87 years old. In this study, it was found that tinea capitis was found mostly in children aged 6-11 years. In general, most of the sexes were male, as many as 764 patients (61.7\%), while women were 474 patients $(38.3 \%)$.

Figure 2 shows the distribution of superficial mycosis cases based on the patient's occupation and the highest number was obtained, namely students 332 (26.9\%) cases, followed by 258 workers (20.8\%) and housewives 231 (18.7\%) cases.

In this study, the regions frequently infected with superficial mycosis were inguinal 338 (18.2\%), abdomen 210 (11.3\%), posterior trunk 205 (11.1\%), and gluteal 199 (10.7\%), respectively. ), whereas the cruris $12(0.6 \%)$ and human $15(0.8 \%)$ regions were the least infected with superficial mycosis (Table 4).

The management used in cases of superficial mycosis in the Dermatology and Venereology Clinic RSMH Palembang during the 2014-2018 period was topical antifungal 656 (53.1) cases and a combination of topical and systemic antifungals in 580 (46.9\%) cases (Figure 3).

Of the 1,222 patients who used topical therapy, 758 (62\%) patients used $2 \%$ ketoconazole cream, followed by ketoconazole $2 \%$ shampoo in 376 (30.7\%) cases. Of the 580 patients who used systemic therapy, 321 
(55.3\%) patients used itraconazole and 212 (36.6\%) patients used ketoconazole (Table 5).

Of the 1,236 new patients with superficial mycosis, it was found that 125 patients had other comorbid diseases (table 6). The most comorbid diseases of 126 superficial mycosis patients were cancer by 21 (16.8\%) and the second highest was cerebrovascular disease and diabetes mellitus by $16(12.8 \%)$. Of the 125 comorbid patients, the majority had a diagnosis of dermatophytosis (34.4\%) and candidiasis cutis $(32.8 \%)$ compared to other diagnoses. The results of statistical tests with chi square, there was a significant relationship between comorbid diseases and diagnosis, Pvalue 0.000 ( $\mathrm{P}<0.05)$.

Table 1. Distribution of cases of superficial mycosis

\begin{tabular}{lllllll}
\hline \multicolumn{1}{c}{ New Case } & $\mathbf{2 0 1 4}$ & $\mathbf{2 0 1 5}$ & $\mathbf{2 0 1 6}$ & $\mathbf{2 0 1 7}$ & $\mathbf{2 0 1 8}$ & $\begin{array}{c}\text { Total } \\
\text { (\%) }\end{array}$ \\
\hline Superficial mycosis & $110(6.9)$ & $264(14.8)$ & $334(23)$ & $289(22)$ & $239(21.8)$ & $1.236(17.1)$ \\
\hline DV Polyclinic & 1.605 & 1.784 & 1.454 & 1.313 & 1.094 & 7.250 \\
\hline
\end{tabular}

Table 2. Distribution of types of superficial mycosis

\begin{tabular}{|c|c|c|c|c|c|c|}
\hline Diagnosis & $\begin{array}{l}2014(\%) \\
n=110\end{array}$ & $\begin{array}{l}2015(\%) \\
n=264\end{array}$ & $\begin{array}{l}2016(\%) \\
n=334\end{array}$ & $\begin{array}{l}2017(\%) \\
n=289\end{array}$ & $\begin{array}{l}2018(\%) \\
n=239\end{array}$ & $\begin{array}{l}\text { Total (\%) } \\
n=1236\end{array}$ \\
\hline Dermatophytosis & $56(50.9)$ & $99(37.5)$ & $126(37.7)$ & $87(30.1)$ & $105(43.9)$ & $473(38.3)$ \\
\hline Tinea corporis & $28(25.5)$ & $39(14.8)$ & $57(17)$ & $36(12.5)$ & $50(20.9)$ & $210(16.9)$ \\
\hline Tinea cruris & $22(20)$ & $32(12.1)$ & $37(11.1)$ & $32(11.1)$ & $36(15.1)$ & 159 (12.9) \\
\hline Tinea capitis & $3(2.7)$ & $10(3.8)$ & $15(4.5)$ & $8(2.7)$ & $5(2.1)$ & $41(3.3)$ \\
\hline Tinea manus & $0(0.00)$ & $1(0.4)$ & $1(0.3)$ & $2(0.7)$ & $1(0.4)$ & $5(0.4)$ \\
\hline Tinea pedis & $3(2.7)$ & $17(6.4)$ & $16(4.8)$ & $9(3.1)$ & $13(5.4)$ & $58(4.7)$ \\
\hline Malassezia & $20(18.2)$ & $106(40.2)$ & $115(34.4)$ & $113(39.1)$ & $83(34.7)$ & $437(35.4)$ \\
\hline Pythiriasis versicolor & $20(18.2)$ & $106(40.2)$ & $115(34.4)$ & $111(38.4)$ & $76(31.8)$ & $428(34.6)$ \\
\hline Malassezia Folliculitis & $0(0.00)$ & $0(0.00)$ & $0(0.00)$ & $2(0.7)$ & $7(2.9)$ & $9(0.7)$ \\
\hline Candidiasis cutis & $13(5.9)$ & $37(14)$ & $27(8.1)$ & $20(6.9)$ & $19(7.9)$ & $116(9.4)$ \\
\hline Onychomycosis & $3(2.7)$ & $4(1.5)$ & $13(3.9)$ & $7(2.4)$ & $2(0.8)$ & $29(2.3)$ \\
\hline Mix & $18(16.4)$ & $18(6.8)$ & 53 (15.9) & $62(21.5)$ & $30(12.6)$ & $181(14.6)$ \\
\hline
\end{tabular}

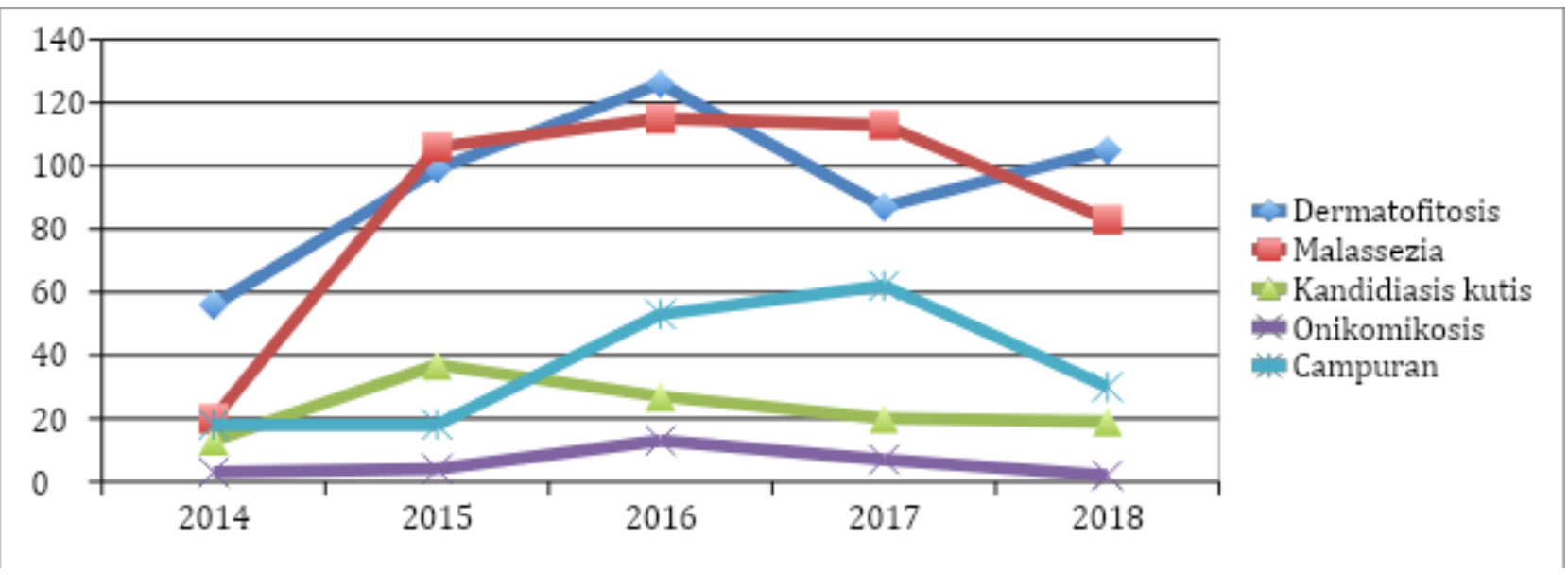

Figure 1. Annual distribution of superficial mycoses 
Table 3. Distribution of superficial mycoses by age group and sex

\begin{tabular}{|c|c|c|c|c|c|c|c|c|c|c|c|c|}
\hline Diagnosis & $0-5$ & 6-11 & $12-16$ & $17-25$ & $26-35$ & $36-45$ & $46-55$ & $56-65$ & $>65$ & $\begin{array}{l}\text { Male } \\
\text { n (\%) }\end{array}$ & $\begin{array}{c}\text { Female } \\
\text { n (\%) }\end{array}$ & $\begin{array}{l}\text { Total } \\
\text { n (\%) }\end{array}$ \\
\hline Dermatophytosis & 10 & 38 & 68 & 77 & 59 & 82 & 83 & 39 & 17 & 252 & 221 & $\begin{array}{c}473 \\
(38.3)\end{array}$ \\
\hline Tinea corporis & 2 & 13 & 25 & 36 & 24 & 34 & 40 & 27 & 9 & 97 & 113 & $\begin{array}{l}210 \\
(17)\end{array}$ \\
\hline Tinea cruris & 2 & 1 & 36 & 31 & 24 & 29 & 25 & 8 & 3 & 92 & 67 & $\begin{array}{c}159 \\
(12.9)\end{array}$ \\
\hline Tinea capitis & 6 & 24 & 3 & 1 & 2 & 2 & 2 & 0 & 1 & 28 & 13 & $\begin{array}{c}41 \\
(3.3)\end{array}$ \\
\hline Tinea manus & 0 & 0 & 0 & 0 & 0 & 3 & 2 & 0 & 0 & 2 & 3 & $\begin{array}{c}5 \\
(0.4)\end{array}$ \\
\hline Tinea pedis & 0 & 0 & 4 & 9 & 9 & 14 & 14 & 4 & 4 & 33 & 25 & $\begin{array}{c}58 \\
(4.7)\end{array}$ \\
\hline Malassezia & 9 & 24 & 94 & 90 & 69 & 72 & 40 & 32 & 7 & 354 & 83 & $\begin{array}{c}437 \\
(35.4)\end{array}$ \\
\hline $\begin{array}{l}\text { Pithiriasis } \\
\text { Versicolor }\end{array}$ & 9 & 24 & 93 & 88 & 68 & 70 & 38 & 31 & 7 & 350 & 78 & $\begin{array}{c}428 \\
(34.7)\end{array}$ \\
\hline $\begin{array}{l}\text { Malassezia } \\
\text { Folliculitis }\end{array}$ & 0 & 0 & 1 & 2 & 1 & 2 & 2 & 1 & 0 & 4 & 5 & $\begin{array}{c}9 \\
(0.7)\end{array}$ \\
\hline Candidiasis cutis & 30 & 6 & 5 & 4 & 9 & 22 & 24 & 10 & 6 & 50 & 66 & $\begin{array}{l}116 \\
(9.4)\end{array}$ \\
\hline Onychomycosis & 0 & 3 & & 1 & 7 & 3 & 8 & 6 & 1 & 14 & 15 & $\begin{array}{c}29 \\
(2.3)\end{array}$ \\
\hline Mix & 1 & 10 & 30 & 34 & 30 & 38 & 14 & 19 & 5 & 94 & 87 & $\begin{array}{c}181 \\
(14.6)\end{array}$ \\
\hline Total & $\begin{array}{c}50 \\
(4.1)\end{array}$ & $\begin{array}{c}81 \\
(6.5)\end{array}$ & $\begin{array}{c}197 \\
(15.9)\end{array}$ & $\begin{array}{c}206 \\
(16.7)\end{array}$ & $\begin{array}{c}174 \\
(14.1)\end{array}$ & $\begin{array}{c}217 \\
(17.6)\end{array}$ & $\begin{array}{c}169 \\
(13.7)\end{array}$ & $\begin{array}{c}106 \\
(8.6)\end{array}$ & $\begin{array}{c}36 \\
(2.9)\end{array}$ & $\begin{array}{c}764 \\
(61.8)\end{array}$ & $\begin{array}{c}472 \\
(38.2)\end{array}$ & $\begin{array}{l}1236 \\
(100)\end{array}$ \\
\hline
\end{tabular}

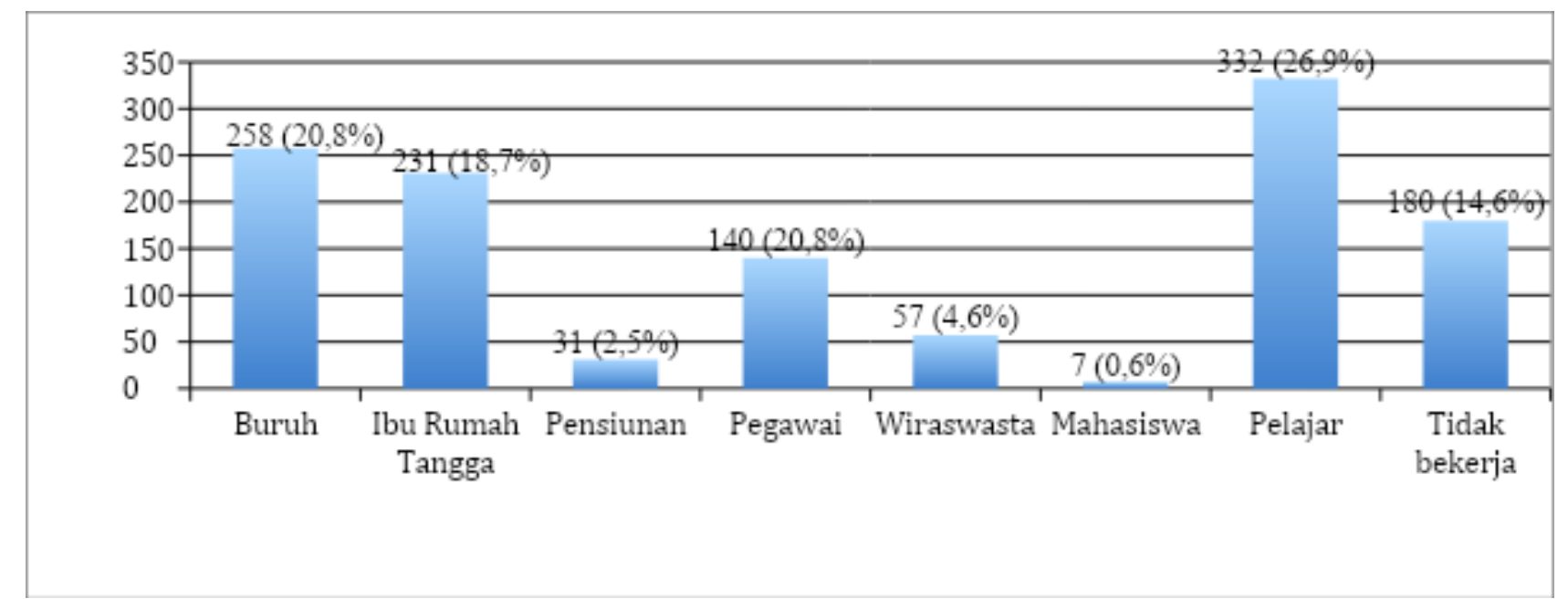

Figure 2. Occupational distribution of the superficial mycoses 
Table 4. Distribution of superficial mycoses by region of infection

\begin{tabular}{lcc}
\hline \multicolumn{1}{c}{ Region Infected } & Total & \% \\
\hline Skalp & 45 & 2.4 \\
Facialist & 154 & 8.3 \\
Colli & 169 & 9.1 \\
Anterior thorax & 162 & 8.7 \\
Axillary & 51 & 2.8 \\
Brachialis \& Antebrachialis & 123 & 6.7 \\
Abdomen & 210 & 11.3 \\
Posterior trunk & 205 & 11.1 \\
Gluteal & 199 & 10.7 \\
Inguinal & 338 & 18.2 \\
Femoral & 39 & 2.1 \\
Kruris & 12 & 0.6 \\
Manus & 15 & 0.8 \\
Pedis & 70 & 3.8 \\
Fingernails & 29 & 1.6 \\
Toenails & 34 & 1.8 \\
\hline Total & $\mathbf{1 8 5 5}$ & $\mathbf{1 0 0}$ \\
\hline
\end{tabular}

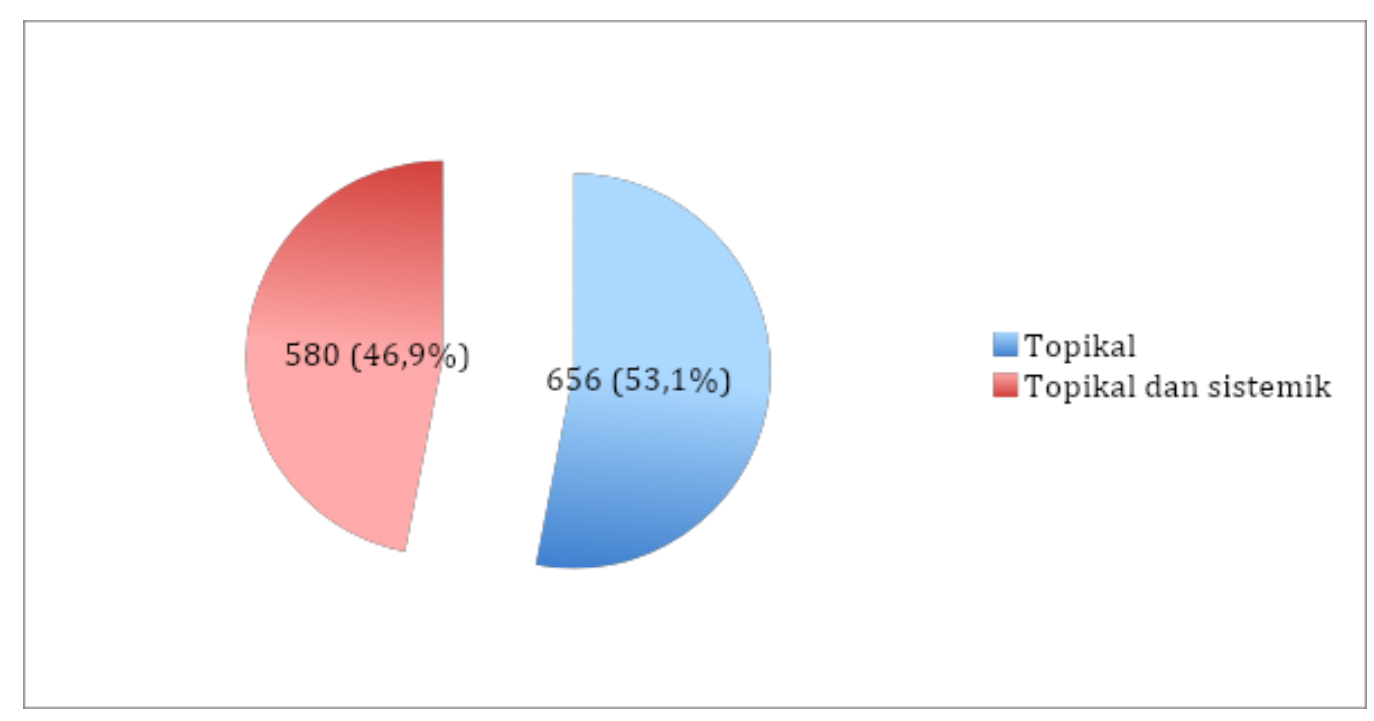

Figure 3. Treatment of superficial mycosis

Table 5. Distribution of management in superficial mycosis

\begin{tabular}{ccc}
\hline Therapy & Total & (\%) \\
\hline Topical & 1.222 & 100 \\
\hline 2\% ketoconazole cream & 758 & 62 \\
\hline Miconazole cream & 61 & 5 \\
\hline Clotrimazole cream & 1 & 0.1 \\
\hline
\end{tabular}




\begin{tabular}{lcc}
\hline Nystatin cream & 3 & 0.3 \\
\hline 2\% ketoconazole shampoo & 376 & 30.7 \\
\hline 2.5\% selenium sulfide shampoo & 8 & 0.7 \\
\hline Solusio resorcinol & 3 & 0.3 \\
\hline 8\% cyclopyrox lacquier & 12 & 0.9 \\
\hline Systemic & 580 & 100 \\
\hline Terbinafin & 4 & 0.7 \\
\hline Griseofulvin & 35 & 6 \\
\hline Ketoconazole & 212 & 36.6 \\
\hline Itraconazole & 321 & 55.3 \\
\hline Fluconazole & 8 & 1.4 \\
\hline
\end{tabular}

Tabel 6. Penyakit komorbid dari 125 pasien mikosis superfisialis.

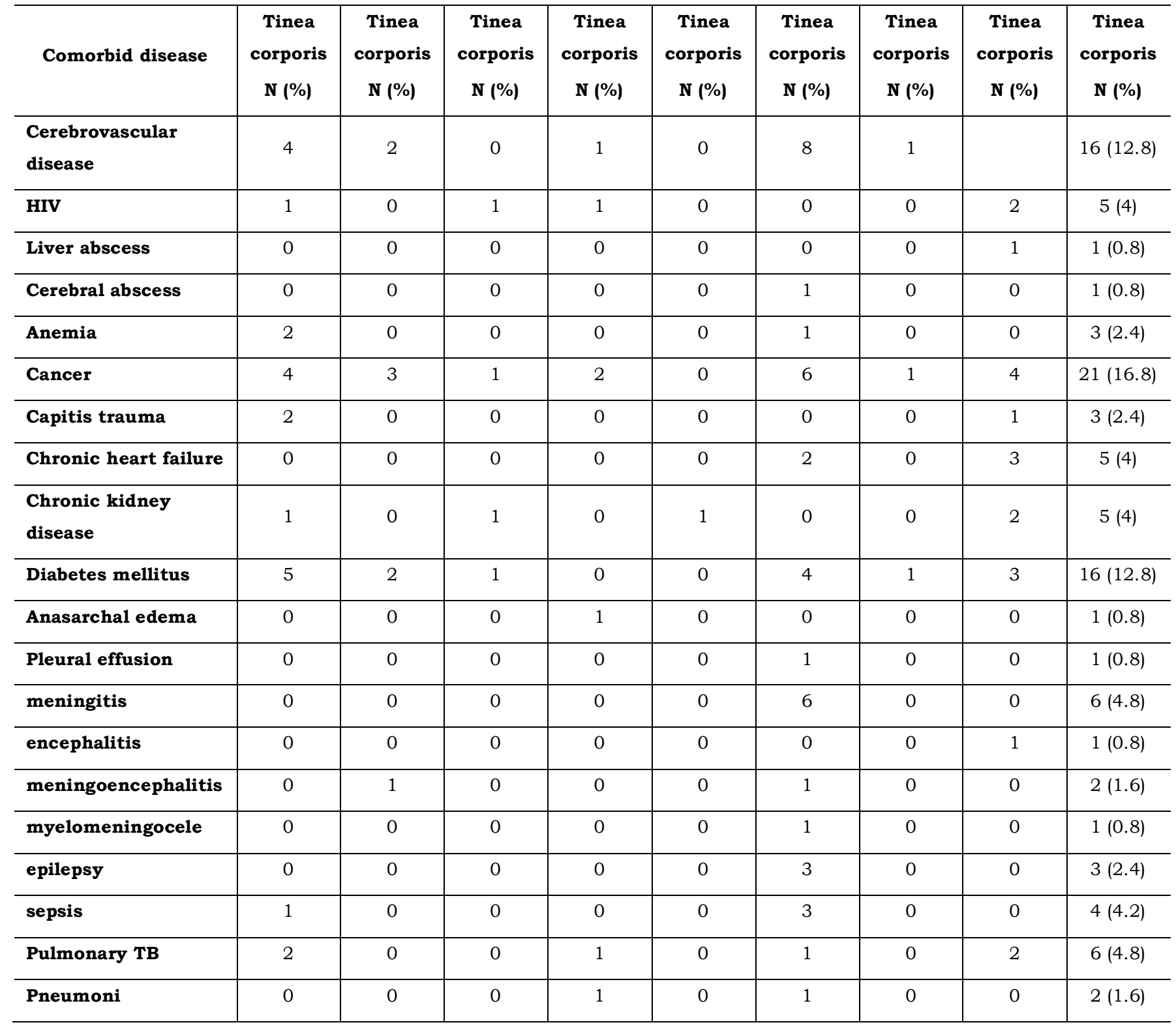




\begin{tabular}{l|c|c|c|c|c|c|c|c|c}
\hline COPD & 0 & 0 & 0 & 0 & 0 & 0 & 0 & 1 & $1(0.8)$ \\
\hline $\begin{array}{l}\text { Patent ductus } \\
\text { arteriosus }\end{array}$ & 0 & 0 & 0 & 0 & 0 & 0 & 0 & 0 & $1(0.8)$ \\
\hline Cushing's Syndrome & 1 & 0 & 0 & 0 & 0 & 0 & 0 & 0 & $1(0.8)$ \\
\hline Nephrotic syndrome & 0 & 0 & 0 & 0 & 0 & 0 & 0 & 1 & $1(0.8)$ \\
\hline SLE & 4 & 2 & 1 & 1 & 1 & 0 & 0 & 2 & $11(8.8)$ \\
\hline Intracranial sol & 0 & 0 & 0 & 0 & 0 & 1 & 0 & 3 & $4(4.2)$ \\
\hline TB spondylitis & 0 & 0 & 0 & 0 & 0 & 0 & 0 & 1 & $1(0.8)$ \\
\hline Hemophilia & 1 & 0 & 0 & 0 & 0 & 0 & 0 & 0 \\
\hline Hypothyroidism & 0 & 0 & 0 & 0 & 0 & 0 & 0 & 1 \\
\hline Total & $\mathbf{2 8}$ & $\mathbf{1 0}$ & $\mathbf{5}$ & $\mathbf{8}$ & $\mathbf{2}$ & $\mathbf{4 1}$ & $\mathbf{3}(0.8)$ \\
\hline
\end{tabular}

\section{Discussion}

The number of new cases of superficial mycosis in the Dermatology and Venereology Polyclinic has shown an increase over the past 3 years with an incidence of more than $20 \%$. The increase in the number of cases is probably due to several factors, such as the majority of the community does not understand about a clean and healthy lifestyle, as well as increased public awareness for treatment. 10

Based on gender, the prevalence of superficial mycosis varies considerably in several countries, generally five times more men than women. ${ }^{11}$ This study showed that superficial mycosis was higher in men than women with a ratio of 1.6: 1. Kumar's research in India also shows that the prevalence of men is more dominant than women with a ratio of $1.12: 1.12$ This is probably due to men more often physical activity outside the home, causing sweating easily thus facilitating the growth of fungi. ${ }^{7}$

In this study, it was found that students and workers most often suffer from superficial mycosis. This research is similar to research by Nayeemuddin SW in India, where it was found that students were most infected with $28.18 \%$ and workers by $20 \% .13$ Research by Fatima Alzahraa in Iraq found that students and housewives were most infected with the fungus. 14 group of patients who have high activity outside the home. Students generally often do sports and play outside the home while workers work more in the field. Hot environmental conditions accompanied by activities that cause sweating and are not balanced with personal hygiene will make it easier to get a yeast infection 15

Superficial mycosis can be found all over the world and affects all ages. ${ }^{16}$ In Indonesia, the age range 2564 years suffers the most from superficial mycosis compared to younger or older people. ${ }^{17}$ In this study, the most superficial mycoses were in the age range of 36-45 years. 217 (17.6\%) cases. Similar results were also found in a study by Sarada in India in 2015, where the highest number of cases of superficial mycosis was in the 31-41 year age group by $26.4 \% .18$ Research in Brazil reported more cases of superficial mycosis in older patients, such as the Costa- Orlandi in 20092010 reported that the highest age group was 41-70 years $68.29 \% .8$ Superficial mycosis infection is more common in adults because at older age there is a change in immune response, and this age group is still of working age, if accompanied by increased physical activity will increase the risk of fungal infection. ${ }^{19}$ In contrast to research in India by Kaur, it was found that the age group 21-30 years of age are more affected by superficial mycosis by $23.3 \% .20$ The same result was also found in the Iranian study by Berenji, which reported that the largest age group was 20-29 years at $35.5 \%$.6 This is probably due to patient age Younger people are more likely to have outdoor activities and 
physical activities, in addition, young patients pay more attention to appearance and seek treatment than older patients. ${ }^{20}$

This study found that dermatophytosis furthermore Malassezia infection was found the most in patients. Several previous studies also reported similar results. Research conducted by Rosida F at the Clinic of Skin and Sex in Dr. Soetomo Surabaya for the period 20112013 reported that dermatophytosis was the most common superficial mycosis disease at $79.50 \%$ while candidiasis and Malassezia infections were the most after dermatophytosis. Research in Singapore by Tan $\mathrm{HH}$ reported that out of 12.903 cases of superficial mycosis, found $57 \%$ were dermatophytosis, Malassezia $25.2 \%$, candidiasis $11.1 \%$ and onychomycosis $6.8 \% .21$ Berenji F et al 2000-2011 in Iran, obtained results in contrast to Malassezia, the most common and the second most common dermatophytosis. Research by Costa-Orlandi CB in 2009-2010 in Brazil found that candidiasis is the most cases of superficial mycosis 6,8

Among the dermatophytosis, the clinical type most often found in this study was tinea corporis 210 $(16.9 \%)$ cases and further tinea cruris amounting to 159 (12.9\%). The results of this study are in accordance with other studies reported by Surekha et al. In 2015 and Gadadavar in 2018.7.22 Research conducted by Lyngdoh $\mathrm{CJ}$ in Meghalaya, India reported different results from tinea pedis which was mostly found at $26.6 \%$. This is because the majority of the population in Meghalaya India wears socks and shoes for a long time accompanied by hot weather which makes fungal infection easier.23 Several studies in developed countries have also reported that the cases of tinea pedis and onychomycosis are higher than other types of superficial mycosis. The high prevalence of tinea pedis and onychomycosis in developed countries is associated with sports activities and the use of closed shoes. ${ }^{24}$

In terms of each case, pityriasis versicolor was the most common of all cases of superficial mycosis, namely 428 (34.26\%). Pythiriasis versicolor spread throughout the world, especially in tropical areas with high temperatures and humidity. Environmental factors (skin moisture) and individual susceptibility factors (genetic predisposition, other underlying diseases, malnutrition) play a role in the pathogenesis of pityriasis versicolor. This factor is widely found in Indonesia, which is a tropical area, so the incidence of pityriasis versicolor is still high 25

In this study, it appears that tinea capitis is more dominant in elementary school age children. Another study also reported the same findings in the group of children aged $0-15$ years, there were $72.7 \%$ cases of tinea capitis. ${ }^{23}$ The Chiacchio study in Brazil from 2005 to 2011 found $42.59 \%$ of tinea capitis in children aged $<10$ years. ${ }^{16}$ This is because children often use combs, hats, towels, frequent contact with other infected children or pets and have not been able to maintain cleanliness. 23

The region most infected with superficial mycosis, namely inguinal at 338 (18.2\%). The inguinal region is an area of the groin that is easily infected with fungi and can be found in tinea cruris and candidiasis cutis. Research by Chiacchio in Brazil found that the most infected anatomical locations were the nails (62.26\%) and the foot region (25.42\%), while the inguinal region was only in the range of $3.42 \% .16$

In addition to environmental and hygiene factors, decreased endurance, comorbid diseases such as endocrine and metabolic disorders are known to play a role in the emergence of superficial mycosis. 10 The Cost-Orlandi study in Brazil, found other comorbid diseases in superficial mycosis patients, most of them hypertension (54.63\%), diabetes mellitus type 2 $(20.37 \%)$, lupus or thyroid disease $(7.4 \%)$, cancer (1.85\%), while AIDS and cardiovascular disease were only $0.92 \% .8$ In this study, the most comorbid diseases were found. cancer by 21 (16.8\%), cerebrovascular disease and diabetes mellitus respectively by 16 $(12.8 \%)$. Cutaneous candidiasis was the most common superficial mycosis in patients with comorbidities, namely 41 (32.8\%).

The choice of antifungal drugs is determined by the extent and severity of the disease, the location of the lesion, co-infection or potential drug interactions, treatment efficacy, price and accessibility and ease of 
use. Antifungal drugs consist of topical and systemic preparations. Superficial fungal infections generally respond well to topical antifungals but systemic treatment is often required. ${ }^{11}$ Tinea capitis and onychomycosis generally require systemic therapy because topical antifungals do not penetrate the hair and nails. 26 In the study, $656(53.1 \%)$ cases received treatment. topical and 580 (46.9\%) cases received combination topical and systemic therapy. This result is different from the research conducted by Bertus in Manado in 2012 where combination therapy was the most widely used therapy for patients, namely $83.08 \% .4$

The topical antifungals that were most widely used in this study were the azole group of $62 \%$ ketoconazole cream $2 \%$ and ketoconazole $2 \%$ shampoo by $30.7 \%$. Azole class topical antifungals are most widely used because of their broad spectrum activity. Topical antifungals belonging to the azole class include ketoconazole, clotrimazole, miconazole, econazole, sulconazole, and oxiconazole. ${ }^{26}$ Nystatin is only effective against candida but is not effective against dermatophytes. 27 Cyclopyrox is a topical antifungal that is effective against dermatophytes and yeasts. Cyclopyrox 8\% nail lacquer has been approved as a therapy for onychomycosis since 1999.26 In this study $12(0.9 \%)$ cases used $8 \%$ cyclopyrox nail lacquer.

The azole drug is currently the most commonly used antifungal for superficial, subcutaneous, and systemic fungal infections. Preparations that can be used systemically include ketoconazole, fluconazole, itraconazole, voriconazole, and posaconazole. Griseofulvin is still considered one of the antifungal options for superficial mycosis, but it is only effective against dermatophytes. second ketoconazole 36.6\%, while griseofulvin ranks third at 6\%.

\section{Conclusion}

The incidence of superficial mycosis in the Dermatology and Venereology Polyclinic of RSMH Palembang for the period 2014-2018 is still quite high, around $17.1 \%$. Mostly found in men, students and workers with an age range of 26-35 years. Dermatophytosis affects most patients followed by
Malassezia infection and candidiasis. Of 1.236 new patients with superficial mycosis, it is known that 125 patients have the most comorbid carcinoma / malignancy, cerebrovascular disease and type 2 diabetes mellitus. Knowing the superficial mycosis profile in patients can be used for preventive measures and health education regarding fungal infections so that it is expected to reduce morbidity.

\section{REFERENCES}

1. Craddock LN, Schieke SM. Superficial fungal infection. In Kang S, Amagai M, Bruckner AL, Enk AH, Margolis DJ, McMichael AJ, et al, editors. Fitzpatrick's Dermatology. 9th ed. New York: Mc Graw-Hill; 2019. P. 2925-51.

2. Bitew A. Drmatophytosis: Prevalence of Dermatophytes and Non-dermatophyte fungi from patients attending arsho advanced medical laboratory, Addis Ababa, Ethiopia. Dermatology Research and Practise 2018: 1-6.

3. Richardson MD, Warnock DW. Fungal infection: diagnosis \& management. 3rd edition, Blackwell Publishing; 2003. p.1-10.

4. Bertus NVP, Pandaleke HEJ, Kapantow GM. Profil dermatofitosis si poliklinik kulit dan kelamin RSUP Prof. DR. Dr. D. Kandou Manado Periode JanuariDesember 2012. Journal e-Clinic 2015; 3(2): 7314.

5. Adiguna MS. Epidemiologi dermatomikosis di Indonesia. Dalam: Ervianty E, Suyoso S, Widaty S, Indriatmi W, Bramono K, Ramali LM, editor. Dermatomikosis superfisialis. Edisi kedua. Jakarta: Balai Penerbit Fakultas Kedokteran Universitas Indonesia 2013. H.1-8.

6. Berenji F, Mahdavi SM, Sadabadi F, Andalib AZ, Ganjbakhsh M, Salehi M. A retrospective study of cutaneous fungal infections in patients referred to Imam Reza Hospital of Mashhad, Iran during 20002011. Curr Med Mycol 2016; 2(1):20-3.

7. Surekha A, Kumar GR, Sridevi K, Murty DS, Usha G, Bharathi G. Superficial dermatomycoses: a prospective clinic-mycological study. J Clin Sci Res 2015; 4:7-15. 
8. Cost-Orlandi CB, Magalhaes GM, Oliveira MB, Taylor ELS, Marques CRS, Resende-Stoianoff MA. Prevalence of dermatomycosis in a Brazilian tertiary care hospital. Mycopathologia 2012; 174: 489-97.

9. Kurniati, Prakoeswa CRS. Etiopatogenesis dermatofitosis. Berkala Ilmu Kesehatan Kulit dan Kelamin. 2008; 20(3): 243-50.

10. Citrashanty I, Suyoso S. Mikosis superfisialis di Divisi Mikologi Unit Rawat Jalan Kulit dan Kelamin RSUD Dr. Soetomo Surabaya Periode Tahun 20082010. BIKKK 2011; 23: 200-6.

11. Rosida F, ErviantiE. Penelitian retrospektif: Mikosis superfisialis. BIKKK 2017; 29(2): 117-25.

12. Kumar K, Kindo AJ, Kalyani J, Anandan S. Clinicomycological profile of dermatophitic skin infections in a tertiary care center- a cross sectional study. Sri Ramachandra J of Med. 2007; 2(1):12-5.

13. Nayeemuddin SW, Mukhi JY, Rambhia KD, Singh RP. Clinico-mycological study of dermatophytosis in a tertiary care hospital in central India. MedPulse International Journal of Medicine 2017; 4(3): 117-21.

14. Alzahraa F, Ali HA, Jawad K, Al-Janabi A, Alhattab MK. Prevalenve of dermatophyte fungal infection in Hillah, Iraq. Int $\mathrm{J}$ of Chemtech Research 2017; 10(6):827-37.

15. Sondakh CEEJ, Pandaleke TA, Mawu FO. Profil dermatofitosis di Poliklinik Kulit dan Kelamin RSUP Prof Dr. R. D. Kandou Manado periode Januari-Desember 2013. Journal e-Clinic 2016; 4(1).

16. Chiacchio ND, Silva CS, Madeira CL, Fernandes LHG, Humaire CR, Reis AL. Superficial mycoses at the hospital do Servidor Publico Municipal De Sao Paulo between 2005 and 2011. An Bras Dermatol 2014; 89(1): 67-71.

17. Riani E. Hubungan antara karakteristik demografi gaya hidup dan prilaku pasien puskesmas di
Jakarta Selatan dengan dermatofitosis. eJKI. 2014; 2: 107-11.

18. Sarada D, Kumari PR. A study of dermatomycoses. IJAR 2015;3(1):582-8.

19. Asticcioli S, Silverio A, Sacco L, Fusi I, Vincenti L, Romero E. Dermatophyte infections in patients attending a tertiary care hospital in northern Italy. New Microbiologica 2008; 31(4): 543-48.

20. Kaur R, Panda PS, Sardana K, Khan S. Mycological pattern of dermatomycoses in a tertiary care hospital. J of Tropical Medicine 2015; p: 1-5.

21. Tan HH. Superficial fungal infections seen at the National Skin Centre, Singapore. J Med Mycol 2005;46: 77-80.

22. Gadadavar S, Shilpa HS, Patil CS, Vinay PS, Shettar N. Clinico-mycological study of dermatophytoses at a tertiary care hospital in Belagavi, Karnataka, India. Int J Curr Microbiol App Sci 2018; 7(5): 1872-80.

23. Lyngdoh CJ, Lyngdoh WV, Choudhury B, Sangma KA, Bora I, Khyriem AB. Clinico-mycological profile of dermatophytosis in Meghalaya. Int J Med Public Health 2013; 3: 254-6.

24. Havlickova B, Czaika VA, Friedrich M. Epidemiological trends in skin mycoses worldwide. Mycoses 2008; vol 51 supplement 4, p:2-15

25. Hidayati, A. N, Suyoso, S, Sandra, E. Mikosis Superfisialis di Divisi Mikologi Unit Rawat Jalan Penyakit Kulit dan Kelamin RSUD Dr. Soetomo Surabaya Tahun 2003-2005. Berkala Ilmu Kesehatan Kulit dan Kelamin 2009;21:1-8.

26. Weistein A, Berman B. Topical treatment of common superficial tinea infections. Am Fam Physician 2002; 65(10): 2095-102.

27. Charles AJ. Superficial cutaneous fungal infections in tropical countries. Dermatologic Therapy 2009; 22: 550-9 